\title{
Speaking an additional language: Can study abroad do the trick?
}

\author{
María Juan-Garau \\ maria.juan@uib.eu \\ Universitat de les Illes Balears, Spain
}

\begin{abstract}
The present article sets out to provide an overall picture of the acquisition of speaking abilities in a given second language acquisition (SLA) learning context, namely study abroad (SA), so as to ascertain whether SA can indeed 'do the trick', as it is popularly assumed, and, if so, under which conditions. Section 1 will characterise the SA context and look at how it can affect oral performance, bearing in mind the opportunities for target language contact and practice it offers learners. Section 2 will focus on the specific linguistic benefits in the oral domain that can accrue in this learning context. In this regard, we will present an overview of empirical research findings with special attention to the SALA (Study Abroad and Language Acquisition) and COLE (Context, Contact and Competence Level) research projects. Section 3 will concentrate on individual variables that may affect oral development abroad in combination with external variables such as SA programme conditions. Finally, Section 4 will provide a summary of the main ideas presented and draw some conclusions.
\end{abstract}

Keywords: study abroad, speaking skills, oral competence, EFL, SLA, learning context

\section{STUDY ABROAD AS A LANGUAGE LEARNING CONTEXT}

Research on bilingualism and multilingualism has paid increasing attention to the learning contexts in which languages are acquired, whether naturalistic or instructed. Such research aims at finding empirical evidence regarding the potential efficiency of a given learning context in promoting students' ability to communicate more fluently, accurately and with higher degrees of complexity in an additional language. In the present article we will focus on the study abroad (henceforth SA) context, situated at the naturalistic end of the learning context continuum (see Juan-Garau 2012, Pérez-Vidal 2011).

As a natural learning setting, SA allows for the testing of learner hypotheses by paying attention to relevant input, for the practice of common speech acts embedded in daily routines, and for the contextualisation of learning in a myriad of authentic situations, enabling better memorisation and retrieval, in contrast to the relative dreariness of 
explicit learning within the confines of a classroom (DeKeyser 1991, Juan-Garau and Pérez-Vidal 2007). SA conditions, thus, allow learners to pay attention to form incidentally while focusing on meaning (Ortega 2005).

SA research has proliferated over the last decades, basically as a result of the increasing number of SA programmes that secondary schools and particularly higher education institutions offer their students as part of their educational experience (Wang 2010), giving rise to a massive-scale student mobility operation in Europe and worldwide. Such research can shed new light on both the positive aspects and the challenges of SA. Most studies of language learners abroad have focused on the acquisition of oral skills, reflecting higher expectations for gains in this area. Indeed, the SA context affords constant opportunities for learners to be exposed to comprehensible input from a plethora of target-language speakers and to practise speaking by getting a variety of things done while interacting and negotiating meaning in a second (L2) or additional language. Learners, however, need to seize the contact opportunities the SA context affords in order to enhance their speaking abilities.

Barbara Freed's 1995 edited volume, entitled Second Language Acquisition in a Study Abroad Context, constituted the first important landmark in the study of the achievements of language learners abroad and inspired further research in this area, which has grown exponentially since then. In his foreword to the volume, as Kinginger (2013) aptly remarks, Charles A. Ferguson referred to the "myths" that surround SA, including the belief that the only way to achieve "real fluency" in an L2 or foreign language is to travel to a place where the target language is spoken. In the next section we will survey SA research that has focused on learners' speaking abilities. In so doing, we will try to dispel some of the myths surrounding oral development in SA settings and to ascertain whether SA can "do the trick" as far as the acquisition of oral competence in an additional language goes.

\section{BENEFITS IN THE ORAL DOMAIN AFTER SA}

Overall oral proficiency, often measured through the ACTFL (American Council on the Teaching of Foreign Languages) Oral Proficiency Interview (OPI) or similar protocols, has been found to register considerable gains abroad (e.g. Isabelli-García 2003, Kang 2014, Lindseth 
2010, Segalowitz and Freed 2004). Research, furthermore, indicates that progress following residence abroad mostly accrues in the oral-aural skills, while it is much less apparent in the written and reading skills (e.g. Brecht and Robinson 1995, Dyson 1988, Lapkin et al. 1995, Meara 1994). We will next examine the domains of complexity, accuracy and fluency (CAF) in relation to speaking skills and will finally consider pronunciation as well. In so doing, we will pay special attention to research conducted as part of the SALA (Study Abroad and Language Acquisition) and COLE (Context, Contact and Competence Level) research projects. ${ }^{1}$

Speech complexity does not seem to increase much as a result of SA. Pérez-Vidal and JuanGarau (2011) examined SALA-COLE project participants' oral productions regarding both syntactic and lexical complexity in the at-home and SA settings. As regards syntactic complexity, clauses per T-unit were seen to decrease slightly at home, while an increase close to significance was registered abroad. Subordination also increased non-significantly in the SA setting, but not at home. Similarly, lexical diversity, as measured by Guiraud's index, registered a non-significant improvement that was more noticeable abroad. Learners significantly increased, nonetheless, their use of formulaic sequences as an effect of the period spent abroad. All in all, these results confirm the findings obtained by Juan-Garau and Pérez-Vidal (2007) with a smaller sample, which showed non-significant increases abroad in the domain of complexity. Similarly, SALA-COLE researchers Mora and Valls-Ferrer (2012) found that the complexity of their participants' oral productions remained largely unmodified. However, Llanes and Muñoz (2013), in a study comparing the effects of SA and at-home learning contexts in children and adult learners, reported significant gains in oral complexity, with the SA setting appearing more beneficial for children's oral skills than for older learners.

As regards accuracy, there is a dearth of SA studies in comparison to the research conducted in relation to fluency. The existing documentation on speaking proficiency reveals that no substantial development tends to take place in the former domain after residence abroad. Thus, Isabelli (2001) examined the null subject parameter and found that L2 Spanish learners abroad benefited from positive evidence, but some problems remained, suggesting restructuring of the parameter but no resetting. Also investigating subject expression in L2 Spanish with oral data, Lopez Ortega (2003) reported that a number of discourse variables affected the presence or absence of subjects. She found signs of progress in her four students after the SA experience, although the quantitative results did not yield conclusive evidence. Based on interviews, picture-sequence tasks and questionnaires, Longcope's (2003) findings indicated that SA had an immediate reflection on learners' fluency, but not necessarily on their grammatical accuracy or syntactic complexity. Similarly, Serrano et al. (2011) reported increased oral fluency and lexical complexity, but not accuracy (or syntactic complexity), for their SA group in comparison with 
the domestic semi-intensive programme. For her part, Torres (2003) investigated the acquisition of Spanish clitics to find that the SA context did not appear to have much linguistic benefit over classroom learning for clitic accuracy and use. Finally, Isabelli-García (2010) found no advantage of the SA abroad over the at-home context in the acquisition of Spanish gender agreement for her intermediate level participants over a four-month period.

Other researchers, however, have provided a rosier view on SA accuracy outcomes. Juan-Garau (2014) examined oral accuracy in forty-three SALA-COLE participants, comparing the gains accrued in the SA context to the gains derived from formal instruction at home. Results showed an advantage for the SA context, where learners became more target-like, with long-lasting effects. Participants with lower pre-departure proficiency levels benefited the most from SA. Some contact variables abroad (e.g. practice of listening and writing activities) were associated with the development of oral accuracy. Similarly, Llanes and Muñoz's (2009) participants improved their oral accuracy rates, measured by means of the ratio of error-free clauses and the average number of errors per clause, after just three-four weeks abroad. For his part, Howard's (2001) SA group reached higher levels of accuracy in aspectual marking in French across a wider range of contexts than the AH groups. Howard (2005) also found a more beneficial effect for SA than for classroom instruction in the expression of past time in natural spontaneous speech for his eighteen Irish learners of French. Likewise, using oral interviews, Isabelli and Nishida's (2005) SA learners showed better performance in the use of the subjunctive in Spanish than the AH groups. After a summer abroad, twenty-two out of thirty L2 Spanish learners in Yager's (1998) study were also observed to improve their grammar, along with their pronunciation and overall oral proficiency, on a nativeness scale. Discrepancies in the findings on oral accuracy following a sojourn overseas evidence the complexity of grammatical development patterns as well as the need for more research in this area.

Oral fluency stands out as the clear winner abroad in comparison with the complexity and accuracy domains. Fluency has been examined with respect to various temporal and hesitation characteristics of speech delivery revealing that SA learners increase the length and rate of their fluent speech runs (e.g. Segalowitz and Freed 2004, Towell et al. 1996) while reducing their pauses and dysfluencies (e.g. Freed et al. 2004, Isabelli-García 2003, Segalowitz and Freed 2004). Nevertheless, several studies have reported that not all learners improve their oral fluency abroad (e.g. Segalowitz and Freed 2004), with individual learner differences accounting for the variability observed. Juan-Garau and Pérez-Vidal (2007) presented evidence from the SALA and COLE projects. They considered the oral linguistic development of twelve CatalanSpanish undergraduate learners of English who spent three months abroad preceded and followed by periods of formal instruction in the at-home setting over the course of three 
academic years. The participants' oral abilities, assessed by means of a role-play conducted in dyads, were positively affected by the SA period, although significant gains were obtained only for the fluency measures. Results also indicated that the opportunities for input and interaction that an SA period provides were conducive to linguistic gains in the oral skills, more so when certain sociolinguistic conditions are met (e.g. working in an international setting with targetlanguage speakers or listening to the media), while other conditions may prove detrimental (e.g. living with Catalan/Spanish companions). Other SALA-COLE researchers have also investigated oral fluency with data elicited through an interview task from advanced learners also involved in these projects. Trenchs-Parera (2009) analysed seven dysfluency phenomena comparing learners' performance to native-speaker baseline data. Her findings unveil SA as a context that helps to correct learners' disruptions, producing the impression of more fluent speech. Mora and Valls-Ferrer (2012), for their part, provide evidence of robust gains in oral fluency as a result of SA (captured mostly through time-related aspects of speech production, such as speech rate, mean length of run, pause frequency and duration, and a composite fluency index), and lack thereof during formal instruction at home (see also Valls-Ferrer and Mora 2014 for similar findings).

Turning to pronunciation, several scholars have focused on the development of SA learners' phonetic and phonological abilities, although this remains a largely uncharted area of research. Previous studies investigating speech learning and phonological acquisition abroad have not shown any consistent improvement in speech production and perception in this learning context. For instance, Simões (1996), Stevens (2001) and Díaz-Campos (2004), focusing on Spanish pronunciation by native speakers of English, reported some benefits in phonological ability for SA students, with the last two studies revealing an advantage of SA over at-home groups in the loss of aspiration when producing unvoiced stops. However, findings in these three studies did not always point in the same direction and did not always report any improvement in the areas considered. Individual differences in the participants and the programmes (e.g. pre-departure proficiency level, length of stay, and time spent using the target language) help to account for differences in pronunciation performance (see section III below).

Research conducted within the SALA-COLE projects has also contributed to analyse the impact of SA on pronunciation. Pérez-Vidal et al. (2011) looked at the perception and production of English vowel contrasts. As regards perception, discrimination scores were always higher in the at-home setting rather than abroad, a finding that was confirmed in a recent study by Mora (2014). This was contrary to our expectations but consistent with previous research (DíazCampos 2004, Mora 2008). As for production, an analysis of duration and frequency measurements of the vowel contrasts considered revealed that most of the vowels SA 
participants produced differed from native speakers' in terms of both their duration and quality (see also Avello and Lara 2014 for comparable results). We concluded that a short-term SA period did not seem to provide enough experience with L2 sounds for changes in the learners' ability to perceive and produce vowel contrasts to develop noticeably. In fact, special focused practice may be needed for those changes to come about (see, for example, Aliaga-García and Mora 2009). Del Río's (2013) study, nevertheless, provides a more positive view of the effects of SA on pronunciation. She examined the development of foreign accent and comprehensibility in the oral productions of 25 adolescent Spanish learners of English before and after a 3-month period of SA. Results showed that SA participants improved significantly between pre-test and post-test in both speech dimensions, thus confirming the beneficial impact of SA context on L2 learners' oral production.

\section{VARIABLES INFLUENCING ORAL GAINS ABROAD}

As already hinted at in section I, it has often been assumed by teachers, students, families and society at large that SA is superior to formal instruction AH for language learning in general and fluency in particular. This belief, however, is often unfounded. In fact, DeKeyser (2007) argues that SA does not always bring about sizeable linguistic gains, as this learning context is not always as obviously ideal to practise a foreign language as people tend to assume. He further claims that the SA and FI contexts are not in opposition, as the declarative and procedural knowledge gathered in the AH setting can bear fruit later on abroad, eventually leading to automatic language use. The problem, however, is that learners abroad, at least to begin with, often feel the pressure to communicate orally in real time and to do so in a fluent and comprehensible manner. Given these difficulties, for SA to bring about language development, certain conditions, to which we turn next, must be met (Pérez-Vidal and JuanGarau 2011).

One major variable affecting SA outcomes is pre-departure proficiency level, often interacting with other individual learner differences. Several studies have indicated that learners may need to have a certain command of target-language lexical and grammatical forms and structures prior to the stay (e.g. DeKeyser 2007, Isabelli and Nishida 2005, Segalowitz and Freed 2004). Thus, the existence of a threshold level for substantial acquisition abroad to take place has been posited. In a recent study by Kang (2014) with Korean university participants learning English, intermediate-level students were the ones who made the most out of their SA period in terms of improving their speaking abilities, while low-level learners' oral skills remained unchanged. These findings appear to lend support to the aforementioned threshold-level tenet that learners 
must have a well-developed lexical and grammatical base to really benefit from SA.

Individual variables are also seen to influence SA gains (Lafford 2006). Among them, learners' readiness and ability to benefit from the contact opportunities at hand has been signalled as an essential factor for SA success. In this respect, Segalowitz and Freed (2004) emphasise the importance of delving into learner-context interactions to explain why a given context may be advantageous to some learners and not others. In fact, Freed et al. (2004) conclude that it is not context per se that promotes language gain, but rather the quantity and quality of contact within that context. In the same vein, Kinginger (2013) underscores the variability in post-SA language learning outcomes and the need to further investigate student activity abroad to be able to understand this phenomenon. Language learning, according to this author, is thus seen "as a dialogic, situated affair that unfolds in intercultural contexts and includes significant subjective dimensions" (Kinginger 2013: 5). Therefore, it is important to consider the extent to which learners abroad engage with the host community, which in turn may be affected by how they are received by the institution where they are to study or by their host families. Students abroad may be eager to seek social interaction or, on the contrary, they may avoid contact with their interlocutors. In the latter case, as Kinginger (2013: 5-6) remarks, they may "cling to social networks of co-nationals, or remain virtually 'at home' via the Internet", an option not available some decades ago that can now greatly diminish foreign language practice abroad. Predeparture preparation can play an important role in avoiding such pitfalls and helping students make the most of their sojourn, as Pérez-Vidal (2014) mentions. The development of selfregulatory strategies among students - including motivation maintenance, goal-setting, and language-learning strategies - is also considered crucial to sustain and intensify foreign language learning abroad (Allen 2013).

Learner attitudes, motivation, and beliefs have also been seen to affect how informal contact abroad relates to acquisition. Thus, Brecht and Robinson (1995: 318) remark that: "Understanding student attitudes may contribute substantively to our knowledge of second language acquisition (SLA) as well as to the success of study abroad programs." These scholars note that students' opinions and beliefs may have an effect on their behaviour and, consequently, influence learning outcomes either positively or negatively. As Churchill and DuFon (2006) indicate in their overview of SA research, several studies have investigated both the effect of pre-departure motivation on the sojourn experience and the effect of time abroad on learner motivation. Hernández (2010) reports that there is a positive relationship between participants' integrative motivation and their interaction with the L2 culture, which, in turn, leads to a significant improvement of their speaking skills (see also Isabelli-García 2006). Yashima et al. (2004), for their part, show that pre-departure attitudinal and motivational 
variables relate to the willingness to communicate and the communication behaviour exhibited by Japanese learners of English while abroad. These authors find that willingness to communicate results in more frequent communication in the L2 (see also MacIntyre 2007), as the learner seeks further opportunities to interact with host nationals and, in turn, that behaviour invites hosts to communicate with the sojourner more extensively, thus reinforcing language development in the L2. Research investigating how the length of the period abroad can affect learner attitude and motivation has not produced consistent findings so far. Allen (2002) finds that her learners do not develop positive attitudes towards French native speakers after six weeks abroad, which makes her question the usefulness of short stays to promote positive attitudes towards the target community. Other studies, however, have reported increased motivation after short-term immersion programmes (e.g. Simões 1996). Thus, SALA-COLE researchers Trenchs-Parera and Juan-Garau (2014) find that the SA period heightens the development of positive motivational stands and the reduction of anxiety. Longer stays have generally been thought to promote integration in the host community and yet some of the learners in Hoffman-Hicks' (1999) study did not develop positive attitudes towards native speakers of the target language even after a year abroad. As Yager (1998) points out, if students spend less than a semester overseas, their attitudes and motivation while abroad become even more important in order to take full advantage of their shorter stay in the host country. Another factor that might interact with learner motivation and attitudes towards the host context is previous linguistic experience. Allen (2002) concludes that her more proficient learners are better prepared to benefit from the opportunities to interact that an SA context offers. Yashima et al. (2004), however, find that it might well be the students' perception of their abilities to communicate in the foreign language - rather than their proficiency level as such - that interacts with their willingness to communicate.

SA programme characteristics can also impinge on learning outcomes (for a review of programme features, see Paige et al. 2002 and Coleman 2013). One of particular significance to learner progress is length of stay. In this respect, as Churchill and DuFon (2006) point out, existing research suggests that (a) even short stays can produce benefits (see, for example, JuanGarau and Pérez-Vidal 2007, Llanes 2010), although (b) longer stays tend to benefit learners more, particularly in the domains of pronunciation and fluency, and (c) learner development only approaches native-like norms at best. Lara (2014), in a study conducted within the SALACOLE framework, explored the linguistic development abroad of learners whose length of stay differed (three vs. six months). She did not find compelling evidence to suggest that a given length of stay was more beneficial than the other in terms of post-SA benefits. Similarly, Llanes (2010) did not find significant differences in the language gains of participants experiencing a 
two- or a three-month stay. These results are indicative that a wider difference in length of stay may be needed (e.g. a semester vs. an academic year) for significant changes to appear.

\section{CONCLUSIONS}

Research to date as regards the development of speaking skills in SA settings reveals that this context - providing extensive opportunities for L2 exposure and practice - has indeed the potential to enhance L2 learners' oral abilities, even though findings are more positive and conclusive for fluency than they are for accuracy and complexity (see, for example, DeKeyser 1991, Freed et al. 2004, Isabelli 2001, Juan-Garau and Pérez-Vidal 2007, Pérez-Vidal and JuanGarau 2011, Segalowitz and Freed 2004, Towell et al. 1996). The latter two domains would possibly show significant gains after longer, or more intensive, periods of immersion abroad than the ones considered herein (Mora and Valls-Ferrer 2012). As for the effects of SA on pronunciation and phonological development, previous research in L2 speech learning has not provided sufficient robust evidence to suggest that an SA setting can enhance L2 speech perception and production. This is an area, however, where more research is clearly needed. It is also important to remark that considerable variation is found both within and across individuals (i.e. intra- and inter-speaker variation) in the literature on language acquisition in SA contexts, which often makes it difficult to draw a linear developmental pattern over time (see, for example, Jensen and Howard 2014).

Considering all of the above, we gather that the SA context can no doubt be advantageous for the development of language learners' speaking skills, but it may end up not being so for all learners (DeKeyser 2007). Consequently, we should bear in mind Freed et al.'s (2004: 298) caveat that: "it is not the learning context per se that promotes various types of learning but rather $[\ldots]$ the nature of the interactions, the quality of the experiences, and the efforts made to use the L2 that render one context superior to another with respect to language gain". Thus, in the preceding section (III), we have considered an array of individual variables that impinge on successful language acquisition abroad, including learners' pre-departure proficiency level and preparation, their readiness to benefit from contact opportunities abroad by engaging with the host community, and the development of self-regulatory strategies as well as positive attitudes, motivational stands and beliefs. These individual variables, often interacting with external variables such as programme characteristics (e.g. length of stay), affect learners' socialization and ultimately their language learning success - or lack thereof - abroad.

Future research should bring together the variables summarised in the previous paragraph to 
provide a fuller characterisation of learners who succeed in improving their speaking skills abroad. As DeKeyser (2014: 321) points out, more fine-grained studies combining quantitative and qualitative data are needed to provide "a reliable documentation of background, process and outcome variables with the in-depth documentation of students' activities, and the quantity and quality of their interactions, especially from the students' perspective".

Intimately connected with the development of linguistic competence in general and of speaking skills in particular, Coleman's (2013) concentric circles model enables us to understand better the dynamic nature of socialization overseas. According to this model, learners gradually move outwards from the inner circle of co-nationals, through contact with other outsiders (generally other international students), towards the outer circle of locals. This progression, Coleman (2013: 31) argues, "is not universal, automatic or uni-directional, but given motivation, time and effort, alternatively labelled agency, movement tends to be centrifugal". He thus clearly pinpoints some of the ingredients that contribute to learners' successful oral development abroad. In their attempt to maximise their SA experience, however, students should not only invest time and effort in language learning but also they should ideally get institutional and pedagogical support in the form of preparatory pre-departure sessions, monitoring during the actual period abroad, and follow-up activities (Beattie 2014). In this sense, Kinginger (2011: 70) states that: "Every effort should be made to ensure that language learners abroad enjoy access to - and engagement in - the practices of their host communities as well as guidance in their efforts to learn and to interpret their experiences". In the same vein, Davidson (2010: 23) claims that residence abroad "holds enormous potential for meeting the needs of education in the 21 st century". To unfold this potential, though, SA needs to be well integrated into the learners' curriculum and well supported by all the stakeholders involved, including of course learners themselves, who should engage actively in their learning process. In sum, as long as the relevant conditions we have outlined are met, SA can do the trick in terms of enhancing learners' speaking abilities.

\section{Notes}

1 These are longitudinal research projects - based at Universitat Pompeu Fabra (Barcelona) in collaboration with the Universitat de les Illes Balears (Palma) - that focus on the acquisition of English as a foreign language by students who partake in SA in addition to formal instruction at home. Learners' language development in these two learning contexts is analysed over a three-year period, contrasted against native-speaker baseline data, and interpreted with the help of qualitative data derived from learner questionnaires and diaries.

Language Value 7, 46-61 $\quad$ http://www.e-revistes.uji.es/languagevalue 
${ }^{2}$ In the case of the SALA-COLE studies which we have reported on, there is no inter-group variation in terms of such variables as motivation, proficiency or gender - among others - as the very same learners participated in both the at-home treatment and the SA period.

\section{Acknowledgements}

This research received financial support through HUM2007-66053-C02-01/02, FFI2010-21483C02-01/02 and FFI2013-48640-C2-2-P from the Spanish Ministry of Economy and Competitiveness. I would like to express my gratitude to the anonymous reviewers of this paper for their suggestions. Thanks are also due to Dr Carmen Pérez-Vidal and the rest of my colleagues in the SALA and COLE projects.

\section{REFERENCES}

Aliaga-García, C. and Mora, J.C. 2009. "Assessing the Effects of Phonetic Training on L2 Sound Perception and Production". In Watkins, M.A., A.S. Rauber and B.O. Baptista (Eds.) Recent Research in Second Language Phonetics/Phonology. Newcastle upon Tyne, UK: Cambridge Scholars Publishing, 2-31.

Allen, H.W. 2002. "Does Study Abroad Make a Difference? An Investigation into Linguistic and Motivational Outcomes". PhD dissertation. Emory University, USA. In Dissertation Abstracts International-A, 63 (4), 1279.

Allen, H.W. 2013. "Self-regulatory Strategies of Foreign Language Learners". In Kinginger, C. (Ed.) Social and Cultural Aspects of Language Learning in Study Abroad. Amsterdam: John Benjamins, 3-15.

Avello, P. and Lara, A.R. 2014. "Phonological Development in L2 Speech Production during Study Abroad Programmes Differing in Length of Stay”. In Pérez-Vidal, C. (Ed.) Language Acquisition in Study Abroad and Formal Instruction Contexts. Amsterdam: John Benjamins, 137-165.

Beattie, J. 2014. "The 'ins and outs' of a Study Abroad Programme". In Pérez-Vidal, C. (Ed.) Language Acquisition in Study Abroad and Formal Instruction Contexts. Amsterdam: John Benjamins, 59-84.

Brecht, R.D. and Robinson, J.L. 1995. "On the Value of Formal Instruction in Study Abroad". In Freed, B.F. (Ed.), Second Language Acquisition in a Study Abroad Context. Amsterdam: John Benjamins, 317-334. 
Churchill, E. and DuFon, M.A. 2006. "Evolving Threads in Study Abroad Research". In DuFon, M.A. and E. Churchill. (Eds.) Language Learners in Study Abroad Contexts. Clevedon: Multilingual Matters, 1-27.

Coleman, J.A. 2013. "Researching Whole People and Whole Lives". In Kinginger, C. (Ed.) Social and Cultural Aspects of Language Learning in Study Abroad. Amsterdam: John Benjamins, 17-44.

Davidson, D. 2010. "Study abroad: When, how long, and with what results? New data from the Russian front”. Foreign Language Annals, 43, 6-26.

DeKeyser, R.M. 1991. "Foreign Language Development during a Semester Abroad". In Freed, B. F. (Ed.) Foreign Language Acquisition Research and the Classroom. Lexington, MA: D. C. Heath \& Co., 104-119.

DeKeyser, R.M. 2007. "Study Abroad as Foreign Language Practice". In DeKeyser, R.M. (Ed.). Practice in a Second Language. Perspectives from Applied Linguistics and Cognitive Psychology. Cambridge: Cambridge University Press, 208-226.

DeKeyser, R.M. 2014. "Research on Language Development during Study Abroad". In PérezVidal, C. (Ed.) Language Acquisition in Study Abroad and Formal Instruction Contexts. Amsterdam: John Benjamins, 313-326.

Del Río, C. 2013. Perceived Foreign Accent and Comprehensibility in the Oral Production of Adolescent Learners of English. Study Abroad vs. At Home Learning Contexts. PhD dissertation. Universitat Pompeu Fabra.

Díaz-Campos, M. 2004. "Context of learning in the acquisition of Spanish second language phonology". Studies in Second Language Acquisition, 26 (2), 249-273.

Dyson, P. 1988. The Year Abroad. Report from the Central Bureau for Educational Visits and Exchanges, Oxford University Language Teaching Centre.

Freed, B. (Ed.). 1995. Second Language Acquisition in a Study Abroad Context. Amsterdam: John Benjamins.

Freed, B., Segalowitz, N. and Dewey, D. 2004. "Context of learning and second language fluency in French: Comparing regular classroom, study abroad and intensive domestic immersion programs". Studies in Second Language Acquisition, 26 (2), 275-301.

Hernández, T.A. 2010. "The relationship among motivation, interaction and the development of second language oral proficiency in a study-abroad context". The Modern Language Journal, 94 (4), 600-617.

Hoffman-Hicks, S.D. 1999. The Longitudinal Development of French Foreign Language Pragmatic Competence: Evidence from Study Abroad Participants. PhD dissertation. Indiana University. 
Howard, M. 2001. “The Effects of Study Abroad on L2 Learners' Structural Skills”. In FosterCohen, S. and A. Nizegorodcew (Eds.) Eurosla Yearbook 1. Amsterdam: John Benjamins, 123-141.

Howard, M. 2005. "Second Language Acquisition in a Study Abroad Context: A Comparative Investigation of the Effects of Study Abroad and Formal Language Instruction on the L2 Learner's grammatical development". In Housen, A. and M. Pierrard (Eds.) Investigations in Instructed Second Language Acquisition. Berlin: Mouton de Gruyter, 495-530.

Isabelli-García, C. 2003. "Development of oral communication skills abroad". Frontiers: The Interdisciplinary Journal of Study Abroad, 9, 149-73.

Isabelli-García, C. 2006. "Study Abroad Social Networks, Motivation and Attitudes: Implications for Second Language Acquisition”. In DuFon, M.A. and E. Churchill (Eds.) Language Learners in Study Abroad Contexts. Clevedon: Multilingual Matters, 231-258.

Isabelli-García, C. 2010. "Acquisition of Spanish gender agreement in two learning contexts: Study abroad and at home". Foreign Language Annals, 43 (2), 289-303.

Isabelli, C.A. 2001. The Impact of a Study Abroad Experience on the Acquisition of L2 Spanish Syntax: The Null Subject Parameter. PhD dissertation. University of Illinois at UrbanaChampaign.

Isabelli, C.A. and Nishida, C. 2005. "Development of Spanish Subjunctive in a Nine-month Study-abroad Setting”. In Edington, D. (Ed.) Selected Proceedings of the 6th Conference on the Acquisition of Spanish and Portuguese as First and Second Languages. Somerville MA: Cascadilla Press, 78-91.

Jensen, J. and Howard. M. 2014. "The effects of time in the development of complexity and accuracy during study abroad". Eurosla Yearbook, 14, 31-64.

Juan-Garau, M. 2012. "Context Matters: Variability across Three SLA Learning Settings". In E. Piechurska-Kuciel and L. Piasecka (Eds.) Variability and Stability in Foreign and Second Language Learning Contexts. Cambridge: Cambridge Scholars Publishing, 220242.

Juan-Garau, M. 2014. "Oral Accuracy Growth after Formal Instruction and Study Abroad: Onset Level, Contact Factors and Long-Term Effects". In C. Pérez-Vidal (Ed.) Language Acquisition in Study Abroad and Formal Instruction Contexts. Amsterdam: John Benjamins, 87-110.

Juan-Garau, M. and Pérez-Vidal, C. 2007. "The effect of context and contact on oral performance in students who go on a stay abroad". Vigo International Journal of Applied Linguistics, 4, 117-134. 
Kang, D-M. 2014. "The effects of study-abroad experiences on EFL learners' willingness to communicate, speaking abilities, and participation in classroom interaction”. System, 42, 319-332.

Kinginger, C. 2011. "Enhancing language learning in study abroad”. Annual Review of Applied Linguistics, 31, 58-73.

Kinginger, C. 2013. "Introduction: Social and Cultural Aspects of Language Learning in Study Abroad”. In Kinginger, C. (Ed.) Social and Cultural Aspects of Language Learning in Study Abroad. Amsterdam: John Benjamins, 3-15.

Lafford, B. 2006. "The Effects of Study Abroad vs. Classroom Contexts of Spanish SLA: Old Assumptions, New Insights and Future Research Directions". In Klee, C. and T. Face (Eds.) Selected Proceedings of the 7th Conference on the Acquisition of Spanish and Portuguese as First and Second Languages. Somerville MA: Cascadilla Proceedings Project, $1-25$.

Lapkin, S., Hart, D. and Swain, M. 1995. "A Canadian Interprovincial Exchange: Evaluating the Linguistic Impact of a Three-month Stay in Quebec". In Freed, B. (Ed.) Second Language Acquisition in a Study Abroad Context. Amsterdam: John Benjamins, 67-94.

Lara, A.R. 2014. Complexity, Accuracy and Fluency Development through Study Abroad Programmes Varying in Duration. PhD dissertation. Universitat Pompeu Fabra.

Lindseth, M.U. 2010. "The development of oral proficiency during a semester in Germany". Foreign Language Annals, 43 (2), 246-68.

Llanes, A. 2010. Children and Adults Learning English in a Study Abroad Context. PhD dissertation. Universitat de Barcelona.

Llanes, A. and Muñoz, C. 2009. “A short stay abroad: Does it make a difference?” System, 37, 353-365.

Llanes, A. and Muñoz, C. 2013. "Age effects in a study abroad context: Children and adults studying abroad and at home". Language Learning, 63 (1), 63-90.

Longcope, P.D. 2003. What is the Impact of SA on L2 Learning? A Descriptive Study of Contexts, Conditions and Outcomes. PhD dissertation, University of Pennsylvania.

Lopez Ortega, N.R. 2003. The Development of Discourse Competence in Study Abroad Learners: A Study of Subject Expression in Spanish as a Second Language. $\mathrm{PhD}$ dissertation. Cornell University.

MacIntyre, P.D. (2007). "Willingness to communicate in the second language: Understanding the decision to speak as a volitional process". The Modern Language Journal, 91 (4), 564-576.

Meara, P. 1994. "The year abroad and its effects". Language Learning Journal, 10, 32-38. 
Mora, J.C. 2008. "Learning context effects on the acquisition of a second language phonology”. In Pérez-Vidal, C., M. Juan-Garau and A. Bel (Eds.) A Portrait of the Young in New Multilingual Spain, 241-263.

Mora, J.C. 2014. "The Role of Onset Level on L2 Perceptual Phonological Development after Formal Instruction and Study Abroad”. In Pérez-Vidal, C. (Ed.) Language Acquisition in Study Abroad and Formal Instruction Contexts. Amsterdam: John Benjamins, 167-194.

Mora, J.C. and Valls-Ferrer, M. 2012. "Oral fluency, accuracy and complexity in formal instruction and study abroad learning contexts". TESOL Quarterly, 46 (4), 610-641.

Ortega, L. 2005. "What do Learners Plan? Learner-driven Attention to Form during Pre-task Planning”. In Ellis, R. (Ed.) Planning and Task Performance in a Second Language. Philadelphia, PA: John Benjamins, 77-110.

Paige, R.M., Cohen, A.D., Kappler, B., Chi, J.C. and Lassegard, J.P. 2002. Maximizing Study Abroad: A Program Professionals' Guide to Strategies for Language and Culture Learning and Use. Minneapolis, MN: Center for Advanced Research on Language Acquisition, University of Minnesota.

Pérez-Vidal, C. 2011. "Language Acquisition in Three Different Contexts of Learning: Formal Instruction, Stay Abroad, and Semi-immersion (CLIL)". In Ruiz de Zarobe, Y., J. M. Sierra and F. Gallardo (Eds.) Content and Foreign Language Integrated Learning: Contributions to Multilingualism in European Contexts. Bern: Peter Lang, 103-127.

Pérez-Vidal, C. 2014. "Study Abroad and Formal Instruction Contrasted: The SALA Project". In Pérez-Vidal, C. (Ed.) Language Acquisition in Study Abroad and Formal Instruction Contexts. Amsterdam: John Benjamins, 17-57.

Pérez-Vidal, C. and Juan-Garau, M. 2011. "The Effect of Context and Input Conditions on Oral and Written Development: A Study Abroad Perspective”. International Review of Applied Linguistics in Language Teaching, 49 (2), 157-185.

Pérez-Vidal, C., Juan-Garau, M. and Mora, J.C. 2011. "The Effects of Formal Instruction and Study Abroad Contexts on Foreign Language Development: The SALA Project”. In C. Sanz and R.P. Leow (Eds.) Implicit and Explicit Language Learning. Conditions, Processes and Knowledge in SLA and Bilingualism. Washington DC: Georgetown University Press, 115-128.

Segalowitz, N. and Freed, B. 2004. "Context, contact and cognition in oral fluency acquisition". Studies in Second Language Acquisition, 26 (2), 173-199.

Serrano, R., Llanes, A. and Tragant, E. 2011. "Analyzing the effect of context of second language learning: Domestic intensive and semi-intensive courses versus study abroad in Europe". System, 39 (2), 133-143. 
Simões, A.R.M. 1996. "Phonetics in second language acquisition: An acoustic study of fluency in adult learners of Spanish". Hispania, 79 (1), 87-95.

Stevens, J.J. 2001. The Acquisition of L2 Spanish Pronunciation in a Study Abroad Context. $\mathrm{PhD}$ dissertation. University of Southern California.

Torres, J.P. 2003. A Cognitive Approach to the Acquisition of Clitics in Spanish: Insights from Study Abroad and Classroom Learners. PhD dissertation. Cornell University.

Towell, R., Hawkins, R. and Bazergui, N. 1996. "The development of fluency in advanced learners of French". Applied Linguistics, 17 (1), 84-119.

Trenchs-Parera, M. 2009. "Effects of formal instruction and a stay abroad on the acquisition of native-like oral fluency". The Canadian Modern Language Review, 65 (3), 365-393.

Trenchs-Parera, M. and Juan-Garau, M. 2014. “A Longitudinal Study of Learners' Motivation and Beliefs in at Home and Study Abroad Contexts". In C. Pérez Vidal (Ed.) Language Acquisition in Study Abroad and Formal Instruction Contexts. Amsterdam: John Benjamins, 259-282.

Valls-Ferrer, M. and Mora, J.C. 2014. "L2 Fluency Development in Formal Instruction and Study Abroad. The Role of Initial Fluency Level and Language Contact". In Pérez-Vidal, C. (Ed.) Language Acquisition in Study Abroad and Formal Instruction Contexts. Amsterdam: John Benjamins, 111-136.

Wang, C. 2010. "Toward a second language socialization perspective: Issues in study abroad research". Foreign Language Annals, 43 (1), 50-63.

Yager, K. 1998. "Learning Spanish in Mexico: The effect of informal contact and student attitudes on language gain”. Hispania, 81, 898-913.

Yashima, T., Zenuk-Nishide, L. and Shimizu, K. 2004. "The influence of attitudes and affect on willingness to communicate and second language communication". Language Learning, 54 (1), 119-152.

Received: 8 June 2015

Accepted: 11 October 2015

Cite this article as:

Juan-Garau, M. 2015. "Speaking an additional language: Can study abroad do the trick?". Language Value 7 (1), 45-60. Jaume I University ePress: Castelló, Spain. http://www.erevistes.uji.es/languagevalue. DOI: http://dx.doi.org/10.6035/LanguageV.2015.7.4

ISSN 1989-7103

Articles are copyrighted by their respective authors 